Wright State University

CORE Scholar

English Language and Literatures Faculty

Publications

English

2005

\title{
Morphine-Addicted Doctors, the English Opium-Eater, and Embattled Medical Authority
}

\author{
Barry Milligan \\ Wright State University - Main Campus, barry.milligan@wright.edu
}

Follow this and additional works at: https://corescholar.libraries.wright.edu/english

Part of the English Language and Literature Commons

\section{Repository Citation \\ Milligan, B. (2005). Morphine-Addicted Doctors, the English Opium-Eater, and Embattled Medical Authority. Victorian Literature and Culture, 33 (2), 541-553. \\ https://corescholar.libraries.wright.edu/english/17}

This Article is brought to you for free and open access by the English at CORE Scholar. It has been accepted for inclusion in English Language and Literatures Faculty Publications by an authorized administrator of CORE Scholar. For more information, please contact library-corescholar@wright.edu. 


\section{MORPHINE-ADDICTED DOCTORS, THE ENGLISH OPIUM-EATER, AND EMBATTLED MEDICAL AUTHORITY}

$$
\text { By Barry Milligan }
$$

IN 1883, the American physician J. B. Mattison made the startling announcement that the majority of American morphine habitues were doctors and suggested that between thirty and forty percent of medical professionals were addicted (23). By 1909, an English addiction specialist had broadened the context and seemingly raised the ante, claiming "that the proportion of medical addicts to the total of cases is in some statistics as high as ninety per cent., and that one-fifth of the mortality in the profession is said to be caused by morphinism" (Jennings, The Morphia Habit v). Looking back in 1924, the German psychopharmacologist Louis Lewin referred to a "statistical table of [morphine] addicts, including all countries of the world," which "gave 40.4 per cent doctors, 10.0 per cent doctors' wives" (54). Of course, all these data are somewhat questionable since reliable measures would have been all but impossible to obtain and the proportions surely varied over the periods and areas in question. But we can reasonably deduce at least this much: medical professionals were consistently the most prominent demographic group among morphine addicts in the developed western world after the middle of the nineteenth century.

Attempting to account for this unsettling fact, observers have tended to emphasize that medical professionals have the easiest access to the drug. This familiar explanation is by no means incorrect, but I will argue in this essay that it is incomplete. The steep rise in the number of morphine-addicted doctors during the latter half of the nineteenth century cannot be properly understood without attention to three contributing factors and the sometimes surprising relationships between them. First, there were several scientific advances involving opium early in the century, dramatically altering the drug's status in medical practice. Second, medical practitioners scrambled to attain a unified and credible public front during the decades surrounding the Medical Reform Act of 1858, and they reacted inconsistently to perceived threats. Third, Thomas De Quincey, author of Confessions of an English Opium-Eater (1821), gradually became the nineteenth century's most celebrated opium pundit and thus a formidable rival to a medical profession whose efficacy and credibility were increasingly dependent upon opiate-based technologies. The pervasiveness of morphine addiction among medical professionals emerged in light of all these factors as a disorganized, not entirely conscious gambit to co-opt the English Opium-Eater's authority while still retaining the cachet of the objective doctor. 


\section{The Evolution of Opiates}

IN ORDER TO CLARIFY the nature and magnitude of De Quincey's challenge to doctors' authority, it will be useful first to trace briefly opiates' changing role in nineteenth-century medical practice. As John Murray put it in A System of Materia Medica and Pharmacy (1832), "As a palliative and anodyne, [opium] is indeed the most valuable article of the materia medica, and its place could scarcely be supplied by any other" (qtd. in Berridge and Edwards 63). ${ }^{1}$ Indeed it is common knowledge that opium long remained the preferred therapeutic recourse for a vast range of complaints from intestinal to bronchial to menstrual to psychological. But in its most common forms - rolled up with chalk into pills, ground into powder, or dissolved in alcohol as laudanum - opium was by no means limited in its utility and importance to professional medical practice, for a dose was readily available for the first two-thirds of the century over almost any tradesman's counter to anyone with the few pence it cost. This easy accessibility of such a powerful and versatile drug accounted in large part for the pervasive self-medication that helped limit the British medical professions to the fragmented, diverse, and not especially respected fields they were until after mid-century. In fact, control of opiates and professional consolidation were twin factors in the growth of the hegemonic monolith the British medical profession is today (and many of the factors were substantially the same in the United States, France, and Germany). ${ }^{2}$ The 1858 Medical Reform Act mooted distinctions between physicians, surgeons, and apothecaries by placing them all on the newly created Medical Register under the uniform heading, "registered medical practitioners." A decade later, the 1868 Pharmacy Act limited the legal sale of opiates to chemists and druggists, officially making opium available to the average consumer only through a licensed chemist, druggist, or registered medical practitioner. ${ }^{3}$ This action dealt a blow to one of professional medicine's stiffest competitors, popular self-medication.

Significantly, the same decade also saw the international advent of a new opiate-based technology that was to reinforce medical authority even further: hypodermically injected morphine. Isolated in 1803 and introduced into general usage by the early 1820s, morphine was from the beginning more a professional tool than a popular one as it was less familiar, less available, and more expensive than unrefined opium. Morphine, an isolated alkaloid, was of a consistent concentration, whereas different batches of raw opium could vary radically in the proportions of their constituents; morphine thus presented the advantage of predictable strength. Nonetheless, no one was certain at first how best to administer it, so it did not immediately catch on. But with the introduction in the mid 1850s of an even more exclusively medical device, the hypodermic syringe, morphine became at once more effective and more restricted to professional medical practice. An injection of "morphia solution" quickly became the doctor's silver bullet, and its unprecedented efficacy in cases of severe pain became even more evident as the new technology swept through military theaters in Europe and the United States during the 1860s. One German doctor attested in 1870 that "I know many physicians who never go out to their practice without a [hypodermic] syringe and a solution of morphine in their pocket, and who usually bring the morphinebottle home empty" (Von Niemeyer 2: 290-91). A decade later the therapy was so woven into the fabric of daily medical practice that, as the author of a standard British medical textbook proclaimed, "The hypodermic syringe and the morphia solution are now almost as indispensable accompaniments of the physician as the stethoscope and thermometer" (Aitken 2: 115). Indeed the image of the doctor as the hierophant of arcane healing technologies 
in the latter third of the century - a trope largely responsible for the steadily increasing status of professional medicine - was inextricably linked to his administration of morphine injections. Said one American practitioner of the new therapy, Henry Gibbons, in 1866, "The patient... gives you credit for a miracle" (qtd. in Morgan 25).

\section{De Quincey's Gauntlet}

WITH THIS NEWFOUND CLAIM to power and authority, doctors after mid-century launched an intensive campaign for exclusive control of morphine injections. One of the earliest contributions to the growing discourse on the morphia habit, Edward Levinstein's monograph of 1878, mourns that the "general public" have taken "out of the hands of the medical man a remedy which, when only in the latter's possession, would have remained a blessing for humanity" (2), and his lament was echoed many times before the turn of the century. Perhaps the most explicit formulation was offered by an anonymous correspondent to the Lancet, who proclaimed that so "formidable a 'remedy' should on no account be used except under medical advice, and when deemed necessary it ought to be given by practitioners.... [S] urgical instrument makers should refuse to sell the requisite apparatus to lay persons, and ... medical men should forbid their use" ("Reckless Use" 538). ${ }^{4}$

Amidst this increasing defensiveness, medical professionals began to perceive challenges to their authority from quarters that had previously gone all but unnoticed. One of the most significant of these was Thomas De Quincey, who coincidentally published a revision of his most popular work just as doctors were becoming hypersensitive about their control of opiates. De Quincey had been both a cult idol for would-be visionaries and the de facto popular authority on all matters related to opium use for more than a generation when he published his 1856 revision of the Confessions of an English Opium-Eater. During the essay's initial burst of popularity - it first appeared in the London Magazine in 1821 and raced through four book editions over the next half decade - the medical profession even shared the general public's high regard for the sagelike Opium-Eater. Although at least one doctor spoke out early on against his dangerous example, ${ }^{5}$ De Quincey's regular appearances in medical discussions of opium for the first two-thirds of the century were usually as an expert on all aspects of the subject - from the highest endurable dose ${ }^{6}$ through responses under different circumstances ${ }^{7}$ to usage among midland laborers. ${ }^{8}$ As an anonymous doctor attested in an untitled Medical Times and Gazette article of 1845, "the law of his self-experience is paramount in the profession," and his "is the only modern instance ... of a non-medical writer submitting, upon a medical subject, an opinion which the whole profession has acknowledged as orthodox testimony" (128).

Such an enthusiastic endorsement is astonishing, given that De Quincey's text is not simply non-medical but staunchly anti-medical. The Opium-Eater claims to "speak from the ground of a large and profound personal experience: whereas most of ... those who have written expressly on the materia medica, make it evident, from the horror they express of [opium], that their experimental knowledge of its action is none at all" (Confessions 1821,357-58). Not content with this subversive appeal to firsthand experience over medical knowledge, De Quincey throws down the gauntlet before medical professionals:

[U]pon all that has been hitherto written on the subject of opium . . . by professors of medicine, writing ex cathedrâ,-I have but one emphatic criticism to pronounce-Lies! lies! lies! ... [T] herefore, worthy 
doctors, as there seems to be room for further discoveries, stand aside, and allow me to come forward and lecture on this matter. (Confessions 1821,356 )

This characteristic audacity only increases as De Quincey tantalizes his readers with a "projected medical treatise on opium, which I will publish, provided the College of Surgeons will pay me for enlightening their benighted understandings upon this subject" (Confessions $1821,366 n)$.

Far from overlooking these insulting challenges, doctors even quoted them directly. The Medical Times and Gazette correspondent, for instance, reprints the worst of them, calling it "a pretty tolerably cool specimen of contradiction." But he proceeds nonetheless to dub the Confessions "one of the most masterly productions that ever issued from human brain ... both in the field of literature and physic" (129). Even the first medical professional contender for the Confessions' authority on opium, Robert Christison's Treatise on Poisons (1829), cites the Opium-Eater approvingly as "a gentleman who writes from personal experience" and calls his descriptions of opium's effects "A very poetical, but I believe also a very faithful, picture of the phenomena" (528). Christison, too, acknowledges De Quincey's pugnacious challenges: "It is singular that our profession should have observed these phenomena so little, as to be accused by the author of having wholly misrepresented the action of the most common drug in medical practice." But instead of challenging the Opium-Eater's accusation, Christison merely gives a bland excuse for what he admits is an extraordinary oversight on the part of the entire medical profession: "In reply to this charge the physician may simply observe, that he seldom administers opium in the way practised by an opium-eater" (527). Christison ultimately grants all De Quincey's claims, not only admitting that he has greater experience but also implicitly acknowledging that such experience constitutes a basis for superior authority on the subject in the first place.

Several factors serve plausibly to account for the medical profession's surprising acceptance of De Quincey's indictments in these early years. For one thing, before the Medical Reform Act of 1858, the community of medical practitioners was fragmented among physicians, surgeons, and apothecaries, and there were so many defamatory salvos passing between these factions that another from beyond the battle lines was unlikely to register as a particular threat with any single group. Additionally, the phenomena upon which De Quincey was later to emerge as the exclusive expert he always claimed to be namely the factors now grouped together under the modern rubrics of "addiction" or "drug dependence" - were not yet regarded as falling within professional medicine's therapeutic domain (as Christison indicates), so De Quincey's claim to expertise in that area did not yet encroach upon any turf doctors recognized as their own. Further dulling the edge of the Opium-Eater's potential threat, after his initial fifteen minutes of fame, he receded into the subcultural background for a whole generation. The fifth edition of the Confessions (1845) was not published until nearly two decades after the fourth (1826), and despite the reams of essays De Quincey produced for Blackwood's and Tait's and a small but devoted following in the United States, he received almost no critical attention during those years.

Following the appearance of both the fifth edition and two sequels to the Confessions, ${ }^{10}$ however, De Quincey's popular fortunes climbed, and although he was always surrounded by controversy he never strayed beyond the corner of the public eye until after the First World War. The 1850s saw the publication of two separate multivolume collected works in both Britain and the United States ${ }^{11}$ and a concomitant burst of literary criticism that tended 
to polarize around the relentlessly first-person point of view inherent in De Quincey's brand of confessional autobiography. Some respondents revered "each personal pronoun [as] an algebraic symbol of great and general truths," while others scorned his prose as "steeped in egotism" or "haunted by the fiend of subjectivity."12 Medical writers kept to the recently entrenched battle lines between subjective poets who breathe "spontaneous wisdom" and objective scientists who "murder to dissect" (in Wordsworth's famous terms) and began to take a stand against De Quincey on this ground of his subjectivism. In addition to sporting a more negative tone - with frequent citations of the Opium-Eater as the seducer of countless doomed addicts, ${ }^{13}$ as a shameless attention-seeker, ${ }^{14}$ or (returning tit for tat) as an outright liar ${ }^{15}$ - the majority of the medical press's allusions to De Quincey in the latter third of the century constitute a collective refutation of his fundamental premise that firsthand experience is a more solid basis for authority than academic knowledge.

The turn of the tide was foreshadowed as early as 1845 with the fourth edition of Christison's Treatise on Poisons. Whereas the first through third editions had ceded authority to De Quincey's account as a "very faithful picture" by "a gentleman who writes from personal experience," the fourth subtly rephrases the parallel passage with potentially damning overtones, referring to "a work well-known to be founded on the personal experience of the writer" (704). It seems hardly coincidental that this change in tone coincides with an increase in Christison's investment in his own authority on the subject: in the years between editions, Christison had begun to focus his study of poisons more pointedly on opium. ${ }^{16} \mathrm{He}$ had also enjoyed his own surge of fame as a star witness in the Earl of Mar life insurance case, which hinged on his expert testimony that habitual opium eating shortened life, a stance that placed him against not only the opinion but ultimately the personal example of the Opium-Eater himself, who lived to be seventy-four. ${ }^{17}$ The anti-subjective trend reached its apogee in the 1890s, when physician Patrick Hehir declared his opposition "to the principle of attaching any great weight to individual opinion, no matter how great be the skill, erudition, and attainments of the person expressing such opinion," and stated that "the opinion of one man is not likely to be of much use in settling a question connected with a habit practised by millions of people" (8-9). Not content with such a clear stand against De Quincey's precedent, Hehir patronizingly dismisses him as all but irrelevant, asserting that the "language of the opium-eater must ... be read with that amount of allowance which we naturally concede to poetical writers, who aim at effect in the language they select, and are not afraid of the startling and uncommon" (264-66).

This trend is not surprising given that, in addition to renewing and expanding his audience, De Quincey's extensive revision of the Confessions reiterates the "ground" of the Opium-Eater's authority - that is, "a large and profound personal experience" of opium as opposed to that of medical writers, whose "experimental knowledge of its action is none at all" $(1821,357-58 ; 1856,199-200)$. The Opium-Eater rubs salt in this reopened wound, again pronouncing "the doctrine of the true church on the subject of opium," speaking not merely as that church's "only member" as he had before (Confessions 1821,357), but now as "the Pope (consequently infallible), and self-appointed legate a latere to all degrees of latitude and longitude" (Confessions 1856, 199). ${ }^{18}$ It makes sense that this enhanced challenge would be more irksome to the medical community the second time around in light of several factors. Apart from the almost shocking implications of the challenge's form - the metaphor of the Pope in an English context casts De Quincey as a well-established and formidable threat from outside - there were several surrounding circumstances that rendered the content more 
threatening as well. First, it appeared when the previously diffused ranks of the medical professions were fighting to pass what was to be the Medical Reform Act of 1858. To a nascent unified profession, De Quincey's belligerent claim could now appear as the focused threat it did not seem when it first appeared in softer form three decades before. Second, the increasing importance to doctors of their new opiate-based therapy, subcutaneously injected morphine, meant that the medical profession's control of opiates was a higher-stakes issue at mid-century than it had been a generation earlier. Third, scientific anti-subjectivism, aggravated by the anti-scientific outcries of the Romantic tribe of which De Quincey was a recognized member, goaded medical practitioners into a more defensive stance against the authority of individual experience in general. Such authority was especially dangerous for doctors to claim in the case of opium, which in addition to its inseparability from the visionary Opium-Eater himself was also increasingly associated with "abuse," "inebriety," and other so-called diseases of the will. Whereas eighteenth-century writers on opium were liberal with their often colorful accounts of self-experimentation, ${ }^{19}$ doctors of Christison's generation not only would have compromised their reputation as objective scientists had they published similar accounts, they would also have risked branding themselves degenerate inebriates.

\section{Medical Ambivalence}

ALTHOUGH IT WOULD PROBABLY be impossible to prove that De Quincey was the chief cause, there was a decisive turn away from invoking self-experimentation in medical discussions of opiates during these decades. There were a few dissenters, such as Dr. James Russell, who cites "my own person" as the subject of one of his case notes on the effects of opium (335) and Dr. Francis Anstie (a notable name here also as an early and aggressive advocate of hypodermic morphine injections), who offers the "effect on myself" as evidence against the De Quinceyan view that opium is a stimulant (79). ${ }^{20}$ But even these departures from the majority view were passing rather than polemical. Medical professionals in general were increasingly reluctant to associate their own persons with opiate use, presumably in large part because what might otherwise be regarded as noble self-experimentation blurred into reprehensible self-indulgence where opiates were concerned.

Despite the many compelling reasons against doctors' claiming De Quincey's brand of subjective authority vis à vis opium, however, there remained one very weighty reason for claiming it: the public honored De Quincey as the expert he claimed to be. It is not surprising, then, that despite the diatribes against De Quincey, medical professionals emerge as ambivalent in the ensuing debate. Even as they refute De Quincey's brand of authority, many of these doctors also attempt to wield it. This paradox is subtly evident in the subtitles to prominent medical professional monographs on the subject, such as Levinstein's, which claims to be "Founded on Personal Observations," and the first edition of Jennings's The Morphia Habit, which advertises itself as "A Personal Relation of a Suppression After Twenty-Five Years' Addiction." But it is especially well-illustrated in the career of H. H. Kane, who accused De Quincey of "hand[ing] down to succeeding generations a mass of ingenious lies" and complained that "such a book as [the Confessions] would create a longing and open the way to a road that has a certain ending in a life's bondage" (Drugs That Enslave 22,33 ). But such convictions did not deter Kane from calling his own program for curing opiate addiction the "De Quincey Home Method" less than two decades later (Berridge and Edwards 163). Kane also ironically made a name for himself in another vein of the De 
Quinceyan tradition as a first-person reporter on drug experiences; his "A Hashish-House in New York: The Curious Adventures of an Individual Who Indulged in a Few Pipefuls of the Narcotic Hemp" (1883) has become a cult classic.

Similarly confused is one of the earliest of the wave of medical professional assaults on the Opium-Eater's authority, Alonzo Calkins's indictment of 1871:

Narratives of isolated instances, fragmentary records of singular personal experiences ... are as sure to put the uninstructed layman upon the wrong tack, as is the fog-whistle to send the ship astrand when some land-lubber, who has not yet had his first exercise upon the nautical alphabet, has been set to guide the helm. (19-20)

This initially seems a straightforward condemnation, but it emerges as more equivocal when the vehicles and tenors of Calkins's extended metaphor are sorted. Yes, the doctor here is the stolid skipper while the layman is the hapless landlubber. But even though the Opium-Eater's signals can mislead, they are far from inherently delusive as Calkins casts them. As the "fogwhistle," they are instead the epitome of firmly founded and benevolent information; their only liability is their susceptibility to misconstruction by the untrained interpreter. Thus, even though Calkins at first seems to impugn the Opium-Eater's authority and ennoble the doctor's, he in fact places the doctor in the subservient position: he is merely the mediator between mysterious wisdom and its uninitiated end-user. If, in other words, the doctor is the priest and the novice opium eater is the parishioner, then Calkins backhandedly endorses De Quincey as the Pope he claims to be. Although Calkins is more scathing later in the same book, referring to the English Opium-Eater as "He that "gropeth at noonday as in the night" $(91),{ }^{21}$ he more frequently reverts to the common habit of citing De Quincey as the default authority, matter-of-factly quoting the Confessions several times as the source of data to support his own assertions $(70,91)$.

Further evidence of such ambivalence throughout the medical community can be found in the case of Sir Robert Christison. The pioneer toxicologist whose eminence as a scientist had enabled him to challenge De Quincey's experience-based authority at mid-century was celebrated by the medical community after his death in 1882 as the kind of noble selfexperimenter De Quincey was often perceived to be. Christison's obituary in the British Medical Journal notes that his vast knowledge of poisons and the materia medica was gained through "experimental researches... which were frequently made on his own person, and sometimes at imminent risk to himself" ("Obituary" 214), and Nature's notice similarly cites "an experiment on his own person" as "a significant indication of the thoroughgoing spirit in which all his researches were pursued" ("Sir Robert" 340). The chronological distance of Christison's death from the mid-century opium poisoning debates (and the obituaries' failure to mention his role in those debates) diminished the probability that audiences would associate such self-experimentation directly with opium. But it remains ironic that the chief medical professional rival for De Quincey's authority, the weight of whose claim rested upon his difference from De Quincey, was ultimately celebrated for his sameness.

These strands of ambivalence and their implications find an especially apt synecdoche in the work of Oscar Jennings, a sometimes controversial but always acknowledged international expert on the treatment of morphine addiction from his first published contribution to the field in 1887 until his death in 1914. Jennings gradually revealed that he had himself been a morphine habitué, but before making his clearest pronouncement on that head, he made 
several coy rhetorical maneuvers, simultaneously claiming and disclaiming the controversial De Quinceyan authority his firsthand experience afforded. He set the tone for his whole career by opening his first monograph along De Quinceyan subjective lines:

I think it was Montaigne who, notwithstanding his general disbelief in medicine, advised the sick to bestow their confidence upon those who have suffered in the same way as themselves. In accordance with this idea, then, I have only to add, in recommendation of the plan set forth in this little volume: Experto crede. (On the Cure 1890, xi)

Even more remarkable than Jennings's endorsement of the suffering patient's authority is his immediately subsequent claim to that authority on his own account: "believe the expert." It does not require much unraveling to ascertain that Jennings is not only admitting here to being or having been a morphine addict himself, he is even asserting his own authority on precisely that basis. But his ambivalence about staking such a claim is suggested by his dressing it up in Latin and his appeal to the fact of his own addiction implicitly rather than directly. The magnitude of his internal conflict becomes evident as he proceeds later in the same volume to impugn the very authority he opened by claiming: "No dependence whatever can be placed upon the statements of morphia patients" who are "of bad faith," he says, and "With all the sympathy I feel for them, I cannot conceal the fact that they are 'prevaricators' by impulse, and sometimes also through interest" $(6,14,62)$. The precarious balance of the latter assertion in particular is almost breathtaking: Jennings's emphasis on his identity with prevaricating morphinists through "all the sympathy [he feels] for them" vitiates the veracity he insists upon with his accompanying assertion that he "cannot conceal" their dissembling nature. The clear professional interests served by Jennings's claims throughout the volume also make his revelation that morphinists prevaricate "through interest" all the more self-damning. The sangfroid with which he thus pulls out from under himself the rug he has carefully placed there is even more evident in the second edition of the same work: "I will say at once, for I have long ceased to make any secret of the matter," he proclaims in the new preface, "that my first observations were made in my own case" (On the Cure 1901, 2). ${ }^{22}$ But, having thus verified his identity as a morphine habitué - and having staked more than ever upon its value as assurance of his own reliability - Jennings goes on to reprint the same pointed indictments of morphinists' veracity that appeared in the first edition. How this dizzying conflict played out in Jennings's own practice can only be imagined, but his sarcastic description of "the argumentative habitué, who knows more about morphia than any doctor living" (On the Cure 1901, 41) evokes images of patients rousing his ire by facing off against him on the same rhetorical basis that underlay his own one-upsmanship with his medical peers: the allegedly superior authority of firsthand experience.

What controversy Jennings did arouse in the medical community always regarded the clinical specifics of his "Physiological Cure of the Morphia Habit" in particular, never the conflicted bases of his claims to authority in general. In fact, far from being interrogated, Jennings's contradictions were repeated by some of his most revered colleagues. The eminent Anglo-Canadian physician Sir William Osler, for instance, warns in his late-century standard textbook The Principles and Practice of Medicine (1892) that the morphia habit "has become so common, and is so much on the increase, that ... under no circumstances whatever should a patient with neuralgia or sciatica be allowed to use the hypodermic syringe" (1007). He issues this warning, however, only after having noted that the malady is "particularly 
prevalent among ... physicians who use the hypodermic syringe for the alleviation of pain, as in neuralgia or sciatica" (1005-06). In other words, Osler is saying both that the needle must on no account be given to the highest-risk patients and that it should be given to no one but them. He thus at once presupposes and undercuts the allegedly impenetrable barrier between doctor and patient upon which his proposed prophylaxis depends.

It is tempting to posit a straightforward cause-and-effect relationship between this pervasive ambivalence and the high incidence of morphine addiction among medical practitioners. Indeed there is even potentially persuasive evidence for such a scenario in documented cases of doctors' becoming addicted to morphine as the direct consequence of attempting to co-opt their patients' firsthand experience. Obersteiner's early contribution to the discourse, for instance, reports the case of a "young medical man" who, when confronted with a morphinist who claimed he must have an injection or die, "was inclined to believe that the patient was romancing, [and] tried the experiment on himself to ascertain what the effects were. The result was that he formed the habit of morphinism, and never could overcome it" (450-51). Even in the face of such evidence, however, it would be reductive to conclude that medical professional morphine addicts like Oscar Jennings turned the syringe on themselves with the calculated intent of attracting hordes of fee-paying morphinists. It would likewise be an irresponsible oversimplification to insist that all doctors who specialized in the treatment of morphine addiction were themselves morphine addicts, or that all medical professional morphine addicts also specialized in the treatment of morphine addiction.

Instead this essay aims at a more provisional conclusion: when juxtaposed against the changing bases of medical authority, opium's centrality in the conflicts surrounding that evolution, and the popular cachet of De Quincey's anti-medical claims to a rival authority, the high incidence of medical professionals' addiction to morphine emerges as one collectively neurotic $^{23}$ result of the medical profession's attempts to reconcile irreconcilable demands. Viewed in the context outlined here, the ambivalent medical stance on opiate use can be seen in large part as a doomed attempt to retain the authority of the objective doctor while assimilating its threatening antithesis, the authority of the subjective patient, all the while striving to maintain the division between the two without which orthodox medical authority would have neither definition nor province.

Wright State University

\section{NOTES}

1. The sixth edition of John Murray's A System of Materia Medica and Pharmacy was published in Edinburgh in 1832. Murray's opinion was seconded by Pereira's Elements of Materia Medica, the standard reference for most of the century: opium held "an interest not possessed by any other article of the Materia Medica" (1301).

2. The system of separate state governments in the United States meant that there could never be legislation on anything like the sweepingly unilateral scale of Britain's 1868 Pharmacy Act, but the same trend was nonetheless underway, if more sluggishly, as evidenced ultimately by the Harrison Act of 1914. And although the United States had no direct parallel to Britain's General Medical Council, the American medical professions were more or less unanimously in agreement with the British in seeing that "strict narcotic laws could be a distinct advantage for institutional development" (Musto 14). 
3. Tempting as it is to emphasize the conspiratorial dimensions of this uneasy alliance, it is nonetheless important to note that there was also a significant public health issue at stake here in the frequency of fatal opium overdoses. Furthermore, the chemists and druggists were well aware of the potential for such a legislative move to backfire insofar as those consumers who had used opium in their own homes for years were not suddenly going to be convinced that it was in their best interests to have it taken from their hands and placed behind the druggist's counter. Such restricted access was also unlikely to limit in any significant way the number of opium poisonings given (a) the strength and longevity of the traditions surrounding popular self-medication and (b) the number of opium overdoses that were not really accidental at all. (For further discussion of the Pharmacy Act's tortured evolution see Peters, and see also Berridge and Edwards.) It is also important to note that although the Pharmacy Act significantly limited public access to opium without medical intervention, it by no means cut it off completely. One of the biggest holes in the dike was that medical prescriptions, once issued, were the property of the patient and could be refilled indefinitely, a hole the medical professions tried to plug beginning in the 1890 s by lobbying for legalization to make prescriptions non-repeatable (see Parssinen and Kerner 291).

4. It would be tempting to interpret this trend as evidence of a cynical conspiracy to cement a medical monopoly were it not for the self-accusatory slant of many of the arguments. Obersteiner, for instance, attributes the spread of the habit to physicians' "carelessly ... leaving morphia and a subcutaneous syringe with the patient" (450), and Kane likewise scolds "physicians [who] are weak enough to place the means of gratifying this morbid appetite directly in the hands of the patient" (Drugs that Enslave 18; see also Drury).

5. Writing in the Morning Chronicle (22 May 1823), a doctor claimed to know of at least four imitators nearly poisoning themselves, and he damned the Confessions as "of universal ill tendency" (qtd. in Lindop 248).

6. McNish (1827; qtd. in North 16), Cooke (1854). De Quincey was still cited as an authority on this matter even by late-century authors who otherwise aggressively impugned his credibility, such as Calkins and Kane, about whom more below.

7. See Christison, Pereira, Johnston, Anstie.

8. See Johnston, Anstie.

9. These terms are subject to much dispute, but there is general consensus at least that the complex phenomena they attempt to describe include tolerance, or the need to increase each dose in order to approximate the effect of the initial dose, and withdrawal, or the onset of pronounced and unpleasant physical symptoms when the accustomed dosage is decreased or discontinued.

10. "Suspiria De Profundis" (1845) and what came to be known as "The English Mail-Coach" (1849; originally published in two parts as "The English Mail-Coach, or the Glory of Motion" and "The Vision of Sudden Death") were the sequels. The fifth edition of the Confessions was published in London by William Smith, 1845.

11. The success of the American De Quincey's Writings inspired De Quincey's friend and publisher James Hogg to undertake, with the author's cooperation, a British collected works, Selections Grave and Gay, From Writings Published and Unpublished, in fourteen volumes published from 1854 to 1860 . Both editions turned enough profit to render the chronically impecunious author prosperous at last in his old age, though he died just before the appearance of the final volume in the British collection (see Lindop 374).

12. From the Eclectic Review (1854), Athenaeum (1859), London Quarterly Review (1857) (qtd. in North 21-23). As North points out, the critics who scorned De Quincey's "egotism" were in powerful company during the $1850 \mathrm{~s}$ and thereafter, falling in line with the rising tide of anti-subjective aesthetics prominently represented by Arnold's preface to his Poems (1853).

13. See Calkins (1871), Kane (1881), Wilson (1886), Hehir (1894). There can be little doubt that the charge was, to a large extent, a just one, as the increasing international popularity of the Confessions over the course of the century spawned a whole underground culture of Romantic opium-eaters. See also Musto, Morgan, Courtwright. 
14. See Calkins, 92.

15. See Calkins (1871), Kane (1881), Sharkey (1887), Hehir (1894).

16. Christison had collaborated with G. R. Mart to study the level of opium dependence among selfmedicating working people (see Berridge and Edwards 35).

17. On Christison's contributions to the longevity debates see Berridge and Edwards, chapter 7 , and Peters 466-68.

18. See also Jack for a brief discussion of other ways in which De Quincey's increased emphasis upon his own medical expertise is evident in the 1856 revision.

19. See, for instance, Young (1753) and Crumpe (1793).

20. There was also the occasional askance invocation of De Quincey as the template for case studies of opium even after the 1856 revision of the Confessions, albeit with strong traces of irony, as in the title of a Dr. Whalley's Lancet article "Confessions of a Laudanum-Drinker," which despite its sensationalistic title is a familiarly bland report about a patient's - rather than the reporting doctor's use of laudanum.

21. Calkins here slightly misquotes from Isaiah 59: 10: "We grope for the wall like the blind, and we grope as if we had no eyes: we stumble at noonday as in the night; we are in desolate places as dead men" (King James Version). It is worth noting that the original casts the blind in collective first-person, thus further dulling the edge of Calkins's would-be accusation.

22. Despite his assertion that he had "long" since gone public with his former addiction, Jennings had first made the claim in print with the publication of the same passage only a few months earlier in the Lancet ("On the Physiological Cure" 360).

23. Allbutt commented on what he clearly regarded as excessive opiate use, "Now, who are the persons who thus indulge themselves? The prompt answer will be - the neurotics. Who, then, are the neurotics? Are we not all neurotics nowadays?" (886).

\section{WORKS CITED}

Aitken, William. The Science and Practice of Medicine. 2 vols. London: Charles Griffin, 1880.

Allbutt, T[homas] Clifford. "Opium Poisoning and Other Intoxications." A System of Medicine By Many Writers. Ed. Thomas Clifford Allbutt. 8 vols. London: Macmillan, 1896-99. 2: 874 920.

Anstie, Francis E. Stimulants and Narcotics, Their Mutual Relations: With Special Researches on the Action of Alcohol, Ather, and Chloroform, on the Vital Organism. London: Macmillan, 1864.

Berridge, Virginia, and Griffith Edwards. Opium and the People: Opiate Use in Nineteenth-Century England. New Haven: Yale UP, 1987.

Calkins, Alonzo. Opium and the Opium-Appetite: With Notices of Alcoholic Beverages, Cannabis Indica, Tobacco and Coca, and Tea and Coffee, in their Hygienic Aspects and Pathologic Relations. Philadelphia: J. B. Lippincott, 1871.

Christison, Robert. A Treatise on Poisons, In Relation to Medical Jurisprudence, Physiology, and the Practice of Physic. Edinburgh: Adam Black; London: Longman, Rees, Orme, Brown, \& Green, 1829.

- A Treatise on Poisons, In Relation to Medical Jurisprudence, Physiology, and the Practice of Physic. 4th ed. Edinburgh: Adam Black; London: Longman, Rees, Orme, Brown, \& Green, 1845.

Cooke, M[ordecai] C[ubitt]. The Seven Sisters of Sleep. Popular History of the Seven Prevailing Narcotics of the World. London: James Blackwood, [1860].

Courtwright, David T. Dark Paradise: Opiate Addiction in America Before 1940. Cambridge: Harvard UP, 1982.

Crumpe, Samuel. An Inquiry Into the Nature and Properties of Opium; Wherein Its Component Principles, Mode of Operation, and Use or Abuse in Particular Diseases, Are Experimentally Investigated; and the Opinions of Former Authors on These Points Impartially Examined. London: G. G. and J. Robinson, 1793. 
[De Quincey, Thomas.] "Confessions of an English Opium-Eater: Being an Extract from the Life of a Scholar." London Magazine 4 (1821): 293-312, 353-79.

De Quincey, Thomas. Confessions of an English Opium-Eater. Rev. ed. Edinburgh: James Hogg, 1856.

Vol. 5 of Selections Grave and Gay, From Writings Published and Unpublished. 14 vols. 1854-60.

—. De Quincey's Writings. 23 vols. Boston: Ticknor, Reed, \& Fields, 1850-59.

. "The English Mail-Coach, or the Glory of Motion." Blackwood's 66 (1849): 485-500.

. "Suspiria De Profundis." Blackwood's 57 (1845): 269-85, 489-502, 739-51; Blackwood's 58

(1845): 43-55.

_. "The Vision of Sudden Death." Blackwood's 66 (1849): 741-55.

Drury, Henry C. “Art. XVI. - Morphinomania.” The Dublin Journal of Medical Science 107 (1899): 321-44.

Hehir, Patrick. Opium: Its Physical, Moral, and Social Effects. London: Baillière, Tindall, \& Cox, 1894.

Jack, Ian. "De Quincey Revises His Confessions." PMLA 72 (1957): 122-46.

Jennings, Oscar. The Morphia Habit and its Voluntary Renunciation (A Personal Relation of a Suppression

After Twenty-Five Years' Addiction). London: Baillière, Tindall, \& Cox, 1909.

- On The Cure of the Morphia Habit. London: Baillière, Tindall, \& Cox, 1890.

. On the Cure of the Morphia Habit Without Suffering (Physiological Demorphinisation) With a Note

on the Physiological Method of Relieving the Craving For Drink. 2nd ed. London: Baillière, Tindall, \&

Cox, 1901.

_. "On the Physiological Cure of the Morphia Habit." Lancet 2 (1901): 360-68.

Johnston, James F. W. The Chemistry of Common Life. 2 vols. Edinburgh: William Blackwood, 1854.

Kane, H[arry] H[ubbell]. Drugs That Enslave. The Opium, Morphine, Chloral and Hashisch Habits.

Philadelphia: Presley, Blakiston, 1881.

. "A Hashish-House in New York: The Curious Adventures of an Individual Who Indulged in a Few

Pipefuls of the Narcotic Hemp." Harper's Monthly 67 (1883): 944-49.

Levinstein, Edward. Morbid Craving for Morphia (Die Morphiumsucht): A Monograph Founded on Personal

Observations. Trans. Charles Harrer. London: Smith, Elder, 1878.

Lewin, Louis. Phantastica: Narcotic and Stimulating Drugs, Their Use and Abuse. 1924. Trans. P. H. A.

Wirth. London: Kegan Paul, Trench, Trubner, 1931.

Lindop, Grevel. The Opium-Eater: A Life of Thomas De Quincey. New York: Taplinger, 1981.

Mattison, J. B. “Opium Addiction Among Medical Men.” 1883. Yesterday's Addicts: American Society and

Drug Abuse, 1865-1920. Ed. H. Wayne Morgan. Norman: U of Oklahoma P, 1974. 62-66.

Medical Times and Gazette: A Journal of English and Foreign Medicine, and Miscellany of Medical Affairs 12 (1845): 128-29, 165-66.

Morgan, H. Wayne. Drugs in America: A Social History, 1800-1980. Syracuse: Syracuse UP, 1981.

Musto, David F. The American Disease: Origins of Narcotic Control. Expanded ed. New York: Oxford UP, 1987.

North, Julian. De Quincey Reviewed: Thomas De Quincey's Critical Reception, 1821-1994. Columbia, South Carolina: Camden House, 1997.

Obersteiner, H. "Chronic Morphinism.” Brain 2 (1879-80): 449-65.

"Obituary. Sir Robert Christison, Bart., M.D., D.C.L., LL.D., Physician in Ordinary to the Queen in Scotland: Vice-President of the British Medical Association, Etc." British Medical Journal 1 (1882): 214-15.

Osler, William. The Principles and Practice of Medicine, Designed for the Use of Practitioners and Students of Medicine. New York: D. Appleton, 1892.

Parssinen, Terry M., and Karen Kerner. "Development of the Disease Model of Drug Addiction in Britain, 1870-1926." Medical History 24 (1980): 275-96.

Pereira, Jonathan. The Elements of Materia Medica; Comprehending the Natural History, Preparation, Properties, Composition, Effects, and Uses of Medicines. 2 vols. London: Longman, Orme, Brown, Green, and Longmans, 1839-40.

Peters, Dolores. "The British Medical Response to Opiate Addiction in the Nineteenth Century.” Journal of the History of Medicine and Allied Sciences 36.4 (1981): 455-88. 
"Reckless Use of Hypodermic Injections." Lancet 1 (1882): 538.

Russell, James. "Clinical Lecture on Opium: Its Use and Abuse." British Medical Journal 174 (1860): 313-15, 334-36.

Sharkey, Seymour. "Morphinomania." The Nineteenth Century 22 (1887): 335-42.

"Sir Robert Christison." Nature 25 (1882): 339-40.

Von Niemeyer, Felix. A Textbook of Practical Medicine With Particular Reference to Physiology and Practical Anatomy. Trans. George H. Humphreys and Charles E. Hackley. 2 vols. London: H. K. Lewis, 1870.

Whalley, W. "Confessions of a Laudanum-Drinker." Lancet 2 (1866): 35.

Wilson, James C. "The Opium Habit and Kindred Affectations." A System of Practical Medicine. By American Authors. Ed. William Pepper and Louis Starr. London: Sampson Low, Marston, Searle and Rivington, 1886. [5] vols. 5: 645-66.

Young, George. A Treatise on Opium, Founded Upon Practical Observations. London: A. Millar, 1753. 